\title{
Guia virtual del col-leccionisme i del mecenatge artístics a Europa (segles XIV-XIX)
}

\author{
Ramon Soler i Fabregat \\ Universitat Autònoma de Barcelona \\ Biblioteca de Comunicació i Hemeroteca General \\ 08 I 93 Bellaterra (Barcelona). Spain \\ ramon.soler@uab.es \\ http://hipatia.uab.es/internart
}

\begin{abstract}
RESUM
Repertori d'unes vuit-centes adreces d'Internet (majoritàriament gratuïtes), per països, regions i èpoques, amb breus comentaris. Inclou Itàlia (unes quatre-centes adreces), Espanya, França, Bèlgica, els Països Baixos, el Regne Unit, Alemanya, Àustria, Bohèmia-Moràvia, Hongria, Dinamarca, Suècia, Polònia i Rússia. Cobreix aproximadament l'Antic Règim, i arriba en alguns casos fins a començaments del segle xx. Tracta l'activitat de sobirans (laics o eclesiàstics), aristocràcia, Tercer Estat (incloent-hi artistes) i organismes civils (universitats, gremis, confraries, etc.), en l'encàrrec i el col-leccionisme d'edificis, jardins, belles arts i llibres. Es tracta la iniciativa privada de membres del clergat, però no els encàrrecs fets per organismes eclesiàstics. No tracta l'activitat de l'administració pública, civil o militar. Ofereix enllaços a monuments, museus, biblioteques, biografies (individuals i familiars), monografies d'artistes, articles de revista, catàlegs de subhastes, etc. Vincles actualitzats l'octubre de 2006.
\end{abstract}

Paraules clau: col·leccions artístiques, mecenatge artístic, Europa, segles xIv-xIx, Internet

\section{RESUMEN}

\section{Guía virtual del coleccionismo y del mecenazgo artístico en Europa (siglos XIV-XIX)}

Repertorio de unas ochocientas direcciones de Internet (la mayoría gratuitas), por países, regiones y épocas, con breves comentarios. Incluye Italia (unas cuatrocientas direcciones), España, Francia, Bélgica, Países Bajos, Reino Unido, Alemania, Austria, Bohemia-Moravia, Hungría, Dinamarca, Suecia, Polonia y Rusia. Cubre aproximadamente el Antiguo Régimen, y llega en algún caso hasta comienzos del siglo xx. Trata la actividad de soberanos (laicos o eclesiásticos), nobleza, Tercer Estado (incluyendo artistas) y organismos civiles (universidades, gremios, cofradías, etc.), en el encargo y coleccionismo de edificios, jardines, bellas artes y libros. Se trata la iniciativa privada de miembros del clero, pero no los encargos hechos por organismos eclesiásticos. No trata la actividad de la administración pública, civil o militar. Ofrece enlaces a monumentos, museos, bibliotecas, biografías (individuales y familiares), monografías de artistas, artículos de revista, catálogos de subastas, etc. Enlaces comprobados en octubre de 2006.

Palabras clave: colecciones artísticas, mecenazgo artístico, Europa, siglos xIV-XIX, Internet

\section{Abstract}

\section{Virtual guide to art collectionism and patronage in Europe, I 4 th-I9th centuries}

Repertory of some eight hundred Internet addresses (mostly open access), by countries, regions and epochs, with brief commentaries. It includes Italy (some four hundred addresses), Spain, France, Belgium, Netherlands, United Kingdom, Germany, Austria, Bohemia-Moravia, Hungary, Denmark, Sweden, Poland and Russia. It covers approximately the Old Regime, until (in some instances) the beginnings of the twentieth century. It deals with the activity of sovereigns (lay or ecclesiastical), nobility, commoners (artists included), and civil corporations (universities, guilds, brotherhoods, etc.) in order to promote and collect buildings, gardens, fine arts and books. It deals with churchmen as private patrons, but does not include Church patronage in general. It does not deal with the activity of public administration, civil nor military. It offers links to monuments, museums, libraries, biographies (individuals and families), artist monographies, journal articles, auction catalogues, etc. Links updated to October 2006.

Keywords: art collections, art patronage, Europe, I4th-19th centuries, Internet 